\title{
Personal Financial Management Behavior of Surabaya College Students
}

\author{
Rini Astuti ${ }^{1}$ \\ 1Universitas Islam Kadiri, Kediri, Indonesia
}

\begin{tabular}{|c|c|}
\hline ARTICLE INFO & ABSTRACT \\
\hline $\begin{array}{l}\text { Keywords: Academic } \\
\text { Ability, Allowance, and } \\
\text { Financial Literacy. }\end{array}$ & $\begin{array}{l}\text { This study aims to analyze the influence of academic ability, and } \\
\text { allowance on the behavior and behavior of college students } \\
\text { managing personal finance, with literacy or financial knowledge } \\
\text { as intervening. This type of research is causal comparative with } \\
\text { quantitative approach. The point of thought used in the research } \\
\text { that is being worked on is the Theory of Planed Behavior (TPB). } \\
\text { The research method used is discovery or quantitative. The } \\
\text { population used is college students who are in Surabaya } \\
\text { universities in the } 2017-2019 \text { school year. Samples in this study as } \\
\text { many as } 100 \text { respondents, by means of data collection using } \\
\text { questionnaires, the way of determining samples to be applied in } \\
\text { this study is stratified random sampling. Analysis helper tools to } \\
\text { process the data that will be used this research is SamartPls } 3 \text { and } \\
\text { hypothesis test. }\end{array}$ \\
\hline
\end{tabular}

\section{Introduction}

At this time the demands of life are rising because of the precariousness and high value of the main commodities. For this reason, it is important to control the usual (medium) cash investments [1]. This suggests avoiding unwanted behavior. Nowadays the way of life is the most taken into account [2]. A lifestyle that seems fun, excessive, spends money without considering starting with western behavior [3].

Extravagant way of life is the tendency of one to devour indefinitely, buy something that exceeds the limits [4]. But in reality, it is usually not based on necessity but because it is based on desire [5]. Among individuals with higher social castes will be role models or commonly called socialites, who seem to view value without taking into account benefits [6]. This requires the ability on the personal finance side, information and understanding of personal finance administration in organizing to keep avoiding extravagant behavior [7].

In general, financial administration is a movement to monitor the budget in life undertaken by one or part of an individual who aims to obtain financial health [8]. By applying the right financial management strategy, an individual is expected to be able to obtain the most extreme benefits through his or her wealth [9]. The understanding of being someone who not only faces almost the same problems with high-level goods such as services, markets, and finances, but this student is more concerned with the need to take on the dangers of more important money in the future [10].

College students are a number of people who can provide assistance for the economy because in the future they will be able to enter the world of work and will start 
individually in managing their own finances, thus the financial proficiency of college students will be appropriate to influence the state of Financial Education Indonesia. Furthermore, college students must be prepared with information and abilities. The goal is that there is no disruption in financial monitoring.

From data taken from Fintek Media "From a total of 64 million people aged 1630 years, it turns out that not all financial literacy". Based on the expression of the Financial Services Authority Reported from the description of Bisnis.com Jakarta Financial Services Authority always strives to empower the expansion of education and financial inquisition, especially among young people, thereby encouraging the goal of budget consideration level of 75\% in 2019. Quoting from the Board of Commissioners of Financial Services Authority Instruction of the President of Buyer Security Tirta Segara "Young-spirited individuals have tremendous potential as a driver of the Indonesian economy both in terms of population forecasts, character, and level of education and monetary incorporation".

Financial literacy is the ability to form coercive choices for the utilization of funds in these circumstances and future financial administration [11]. Agree with the opinion of experts with previous research on finance, where there is an opinion that the urgency of money related proficiency cannot be exaggerated, because an individual who is not fiscally educated is unlikely to be legally supervised for the fulfillment of costs, so that a person is judged unable to elaborate on the budget on which goods or administration are available [12]. meet his needs, do not use understanding to acquire and assess a financial freely.

Allowance is the largest salary resource for college students [4]. The results of previous research say that cash deposits have a critical impact on education related to money. Remittances can encourage the community to supervise the cash as best as possible, because it can provide opportunities for both parents to channel the use in order to educate the child as best as possible. However, it is not like-minded with the findings of other studies that state that cash deposits have a considerable influence and there is a negative relationship with budget proficiency [6]. This situation provides a bright spot that if the allowance is low or negative, the increase in financial or financial literacy of an individual. On the other hand, if the allowance is more positive then financial education will decrease.

Academic ability can be a consideration that has to do with financial literacy and individual student financial management behavior [8]. College students' academic ability or proficiency can be a measure of effectiveness obtained by college students in meeting the final score of each program and scientific practicum achievement within a certain period of time. The achievement of studying in the field of scholastic can be seen from the Grade Point Average (GPA) obtained during the exams in college. GPA itself may be a plus consisting of different courses in the middle of the end of the semester. The results of previous research clarified that GPA has an impact on the level of literacy related to student wear and tear. Thus, it can be said that the higher the student GPA, the better the level of literacy or knowledge related to finance, and the lower the student GPA the lower the level of financial literacy. Another study stated that GPA factors do 
not have a significant influence on student financial proficiency. Because college students with higher GPAs have higher money-related education as well.

College students who have a poor level of financial literacy tend to do unhealthy financial management patterns; this is due to a lack of education about the basic concept of money management. College students will never get caught up in extravagant or consumptive attitudes if they have good financial knowledge and skills in devising personal financial strategies in their daily lives, therefore the author will conduct a study titled "The Influence of Allowance and Academic Ability on Personal Financial Management Behavior of Surabaya College students with Financial Literacy as Intervening Variables (Case Study on Surabaya College students)".

\section{Research Methods}

Articles include Allowance, Academic Ability, Financial Literacy, Personal Finance Management Behavior.

\section{Result and Discussion}

Allowance: allowance is money that is given to be spent at any time, which is usually given to children who do not have an income and with a not very large amount. Allowance is one of the factors that can influence a person in determining how to manage finances, so that the money provided by parents can be used for other important purposes such as transportation and investment funds. Allowance can also be used to buy ingredients for consumption and other important expenses. The goal is to provide learning media for individuals in order to monitor finances properly.

According to the article made by the Ministry of Education, the things that need to be considered in giving allowance are as follows:

1. Give allowance according to the age stage $>$ Because the greater the age of the child, the greater the allowance that must be given. A child with a more mature age definitely needs more needs so he needs more allowance to live up to those needs.

2. The distance between school and home $>$ The children who go and come to school together with their parents will definitely be different from the amount of allowance given inversely compared to children who have to use public transportation in traveling to their destination.

3. What activities he participates in $>$ Children who actively participate in more activities than usual such as extracurricular activities or other organizations that need extra allowance to meet their needs.

4. Also pay attention to how much allowance is earned by friends his age $>$ Do not let the child receive too large amounts, and not too little. Calculate the amount that suits the needs of the child.

Academic ability: college student's academic ability is decomposed in the lecture process by practicing psychomotor, affective (behavioral attitudes) and cognitive skills (practicum or work). With the 3-way capability component, college student's learning ability increases and learning outcomes can be seen from the cumulative index per semester or the cumulative index as a whole. High Grade Point Average (GPA) is the desire of every college student, but with a high GPA the struggle is not completed until 
the final judge, there is a struggle managed with good time management. Can also fight for it every semester with a variety of lecture activities.

Measure of college student success rate in the form of achievement index and academic ability. On the other hand, activities outside the academic field also need to be a special concern and need good management for college students. Special abilities of college student interest talents can be managed in college student activities from certain unit areas, namely sports and arts.

The assessment of college student's activity credit units is formed and collected by the selected field during a certain period which will be accumulated into the full activity value during the lecture period and becomes a special requirement before the lecture. So that with non-academic activities, college students are expected to learn a lot about college student activity management skills and hone soft skills so that college students become resilient, can cooperate with the world of organization and can develop the talents of college student interest to be felt and with the activities of college students can reduce outside activities. But it is also undeniable that the limitations of college student activities are also inseparable from hobbies and talents other than existing ones, which can later be honed and developed in college. And there is no denying that the need for process and support from various parties to be effective and other college students can participate in the activity.

Financial literacy: From the presentation presented by Kusumaningtuti S. Soetiono and Cecep Setiawan (2018) knowledge or commonly called literacy, in general can be interpreted as a practice in social relations related to knowledge, language, and culture that includes how one relates to society. While in the opinion of other experts stated that literacy includes one's expertise to process and understand with the information read written. Finance is a science that covers with assets.

Referring to the Circular Letter of the Financial Services Authority No. 30/SEOJK. /07/2017 financial literacy is knowledge, skills, and beliefs, which affect attitudes and behaviors to improve the quality of decision making and financial processing. Financial literacy is one's skill to manage finances for future lives. The objectives of financial literacy according to the Financial Services Authority are:

1. Growing the level of literacy of individuals who previously did not know about financial literacy or did not even know at all about financial literacy became aware of financial literacy.

2. Growing the number of users of financial products and services.

Personal finance management behavior: financial management is a process of the overall view of one's personal finances, from various points of view of financial management, such as assets and assets available. The assets are used to overcome financial problems and fulfill the desire to start a systematic process. Nyoman Trisna Herawati (2018) said that student financial behavior is a behavior in managing their personal finances to manage the allowance provided by parents wisely.

Money-related administrative behavior can be measured by using five components of an individual's capacity to budget, set aside cash, and oversee costs. The five components are being able to spend or utilize cash as needed, pay monthly fees on time, arrange money for future needs, save reserve funds, and set aside for yourself and 
family. With respect to Bank Indonesia, the objectives of individual financial administration are as follows:

1. Reach certain funding targets in the future.

2. Protect and increase the assets owned.

3. Manage cash flow.

4. Conduct risk management and manage risk well.

5. Manage receivables.

\section{Conclusion}

From the dialogue above, it can be concluded that the level of literacy and management of the individual budget of college students today, especially among the bookkeeping college students is still low. So, the government seeks to improve monetary education, one of which is by opening a reserve fund account or bank account. With these allowance, sexual orientation, and scholastic abilities are associated with financial literacy. As well as saving money, gender, scientific capacity and literacy financial relationships with money related to the administrative behavior of personal bookkeeping college students. Lastly there is a relationship of salary, gender, and scientific ability with the behavior of personal bookkeeping financial administration and student financial education as interrelated variables.

\section{References}

[1] Karimi, S., Biemans, H., Lans, T., Chizari, M., \& Mulder, M. (2016). The impact of entrepreneurship education: A study of Iranian students' entrepreneurial intentions and opportunity identification. Journal of Small Business Management, 54(1), 187-209.

[2] Gautam, M. K., \& Singh, S. K. (2015). Entrepreneurship education: Concept, characteristics, and implications for teacher education. Shaikshik Parisamvad (An International Journal of Education), 5(1), 21-35.

[3] Permatasari, A.; Erstiawan, MS.; 2013. Keberlanjutan Kurikulum Berbasis Kompetensi Dalam Meningkatkan Mutu Pendidikan Akuntansi pada 5 (Lima) Perguruan Tinggi Swasta di Surabaya. BIP's Jurnal Bisnis Perspektif 5 (2), 123-156.

[4] Oguntimehin, Y., Abiodun, O., \& Oyejoke, O. (2017). The relationship between entrepreneur education and students' entrepreneurial intentions in Ogun State universities, Nigeria. British Journal of Education, 5(3), 9-20.

[5] Santoso, R.; Erstiawan, MS.; Mujayana, M. 2018. Review of Virtual Currency Potential as a Payment Instrument in Legal Aspect in Indonesia. IJBMI. Volume 7 Issue 12. 158-167.

[6] Santoso, R., Shinta, R., \& Fianto, A. Y. A. (2019). Pengaruh Bauran Pemasaran Jasa terhadap Keputusan Berkunjung ke Wisata Bahari Jawa Timur. Jurnal MEBIS (Manajemen dan Bisnis), 4(2), 73-86.

[7] Hui-Chen, C., Kuen-Hung, T., \& Chen-Yi, P. (2014). The entrepreneurial process: An integrated model. The International Entrepreneurship and Management Journal, 10(4), 727-745. 
[8] Fianto, A. Y. A. (2020). Satifaction as intervening for the antecedents of intention to revisit: Marine tourism context in East Java. Relasi: Jurnal Ekonomi, 16(1), 179207.

[9] Zapkau, F., Schwens, C., Steinmetz, H., \& Kabst, R. (2015). Disentangling the effect of prior entrepreneurial exposure on entrepreneurial intention. Journal of Business Research, 68(3), 639-653. 